\title{
UPAYA PENINGKATAN MINAT BELAJAR SISWA PADA PEMBELAJARAN PKn MENGGUNAKAN MODEL PEMBELAJARAN KOOPERATIF TIPE NUMBERED HEAD TOGETHER (NHT) KELAS VIII SMP BAITURRAHMAH PADANG
}

\author{
SRI DELI, S.H. \\ SMP BAITURRAHMAH PADANG
}

\begin{abstract}
Abstrak
Penelitian ini dilatar belakangi dari kurangnya minat belajar siswa pada pembelajaran PKn, penulis mencarikan solusi melalui model pembelajaran kooperatif tipe Numbered Head Together (NHT). Teori yang mendukung pelaksanaan penelitian ini adalah teori minat belajar, teori model pembelajaran kooperatif tipe Numbered Head Together (NHT) dan teori pembelajaran PKn dengan metode penelitian tindakan kelas di SMP Baiturrahmah Padang. Waktu pelaksanaan penelitian ini periode Januari-Juni semester 2. Penelitian ini memakai siklus sesuai dengan prosedur, dengan peningkatan minat belajar siswa kelas VIII SMP Baiturrahmah Padang melalui model pembelajaran kooperatif tipe Numbered Head Together (NHT). Hasil penelitian menunjukkan terdapat peningkatan minat belajar siswa dengan menggunakan model pembelajaran kooperatif tipe Numbeed head together (NHT) dalam pembelajaran PKn yang dibuktikan pada siklus II minat belajar siswa tinggi sebesar $88 \%$ berdasarkan hasil penelitian, dapat disimpulkan bahwa penggunaan model pembelajaran kooperatif tipe Numbered Head Together (NHT) dalam pembelajaran dapat meningkatkan minat belajar PKn siswa kelas VIII SMP Baiturrahmah Padang.
\end{abstract}

\section{PENDAHULUAN}

Minat belajar sangat penting dalam proses pembelajaran, tanpa adanya minat belajar siswa tidak memiliki keinginan dan ketertarikan dalam melaksanakan proses pembelajaran. Karena proses pembelajaran terjadi hanya satu arah.Tidak semua orang belajar memiliki minat belajar yang tinggi. Hal ini terjadi karena kurangnya perhatian siswa dalam pembelajaran dan kurang. Sehingga dalam pembelajaran peran guru harus lebih dimaksimalkan agar siswa tertarik dalam proses pembelajaran kreatifnya guru. Kondisi seperti ini juga terjadi ditempat kami bertugas. Dimana dalam proses pembelajaran guru hanya melakukan pembelakaran secara konvensional saja. Seringkali dalam pembelajaran hanya menggunakan metode ceramah. Hal ini yang menyebabkan kurangnya minat siswa belajar. 
Penulis mencoba mencari solusi melalui Model pembelajaran kooperatif tipe Numbered Head Together (NHT). NHT merupakan salah satu model yang dapat digunakan dalam proses pembelajaran. Dimana siswa diharapkan dapat berinteraksi dalam memecahkan masalah secara bersama-sama dalam sebuah kelompok kecil Sehingga siswa kelas VIII tidak lagi bosan pada mata pelajaran PKn.

Berdasarkan latar belakang di atas, maka penulis merumuskan masalah penelitian ini adalah bagaimana gambaran peningkatan minat belajar siswa pada pembelajaran PKn menggunakan model pembelajaran kooperatif tipe Numbered Head Together (NHT) di kelas VIII SMP Baiturrahmah Padang. Dari rumusan masalah di atas penulis menyusun tujuan penelitian ini agar lebih terarah dan terfokus seperti di bawah ini: untuk mendeskripsikan peningkatan minat belajar siswa pada pembelajaran PKn menggunakan model pembelajaran kooperatif tipe Numbered Head Together (NHT) di kelas VIII SMP Baiturrahmah Padang.

Penelitian ini diharapkan bermanfaat untuk:

1. Siswa

Pelaksanaan PTK akan sangat membantu siswa dalam mencapai tujuan pembelajaran secara optimal. Dengan adanya pembaharuan dalam pembelajaran akan memungkinkan siswa terlibat secara aktif alam proses belajar mengajar, mengembangkan daya nalar dan mampu berfikir secara kreatif, sehingga siswa temotivasi untuk mengikuti proses pembelajaran. Dan juga, untuk peningkatan minat belajar siswa dalam proses pembelajaran.

2. Penulis

Pelaksanaan PTK dapat menumbuhkan budaya meneliti di kalangan guru sehingga akan dapat meningkatkan profesionalisme guru. Selain itu juga kemampuan guru dalam mengelola pembelajaran di kelas akan meningkat,membuat guru sebagai peneliti sedikit demi sedikit mengetahui strategi, media maupun metode pembelajaran yang sesuai dengan tujuanatau kompetensi dasar pembelajaran.

3. Sekolah

Hasil penelitian tindakan kelasini diharapkan dapat menunjang pencapaian visi dan misi sekolah, dapat meningkatkan mutu pendidikan, sangat bermanfaat dalam rangka perbaikan sistem pembelajaran, sekaligus bagi guru yang lain dapat juga digunakan sebagai referensi dalam memilih dan menerapkan suatu strategi, metode atau media yang sesuai dengan tujuan dan kompetensi pembelajaran tertentu.

\section{KAJIAN PUSTAKA}

\section{A. Minat Belajar}

1. Pengertian Minat Belajar

Lingkungan sebagai sumber belajar adalah system kondisional yang mempengaruhi tingkah laku individu yang dapat membangkitkan minat siswa dalam belajarnya. Adapun pengertian mengenai minat 
antara lain: minat adalah kecenderungan hati yang tinggi terhadap sesuatu (Kamus Besar Bahasa Indonesia 1989). Pendapat lain menurut Sudjana 1991: 24) "Minat berasal dari pengalaman yang dilakukan sesuatu yang menarik akan mendatangkan kesenangan yang sangat besa pengaruhnya pada diri sendiri sehingga timbul keingintahuan yang mendalam".

Menurut Hiltgard (1997: 19) memberi rumusan pengertian tentang minat sebagai berikut: "Interest is persisting tendency to pay attention to and enjoy some activity or content" yang berarti minat adalah kecenderungan yang tetap untuk memperhatikan dan mengenang beberapa kegiatan. Kegiatan yang diminati seseorang, diperhatikan terus menerus yang disertai dengan rasa senang dan diperoleh suatu kepuasan.

Menurut Slameto (2003:57) minat adalah kecenderungan yang tetap untuk mempehatikan dan mengenang beberapa kegiatan. Kegiatan yang diminati siswa, diperhatikan terus menerus yang disertai rasa senang dan diperoleh rasa kepuasan. Lebih lanjut dijelaskan minat adalah suatu rasa suka dan ketertarikan pada suatu hal atau aktifitas, tanpa ada yang menyuruh.

Minat adalah kecenderungan dalam diri individu untuk tertarik pada sesuatu objek atau menyenangi sesuatu objek (Sumadi Suryabrata, 1988 : 109). Minat adalah sesuatu pemusatan perhatian yang tidak disengaja yang terlahir dengan penuh kemauannya dan tergantung dari bakat dan lingkungan.

Dari beberapa pengertian diatas dapat disimpulkan bahwa minat adalah kecenderungan tertarik pada sesuatu yang relative tetap untuk lebih memperhatikan dan mengingat secara terus menerus yang diikuti rasa senang untuk memperoleh suatu kepuasan dalam mencapai tujuan pembelajaran.

Indikator-indikator minat belajar siswa terdiri dari : adanya perhatian, adanya ketertarikan dan rasa senang. Indikator adanya perhatian dijabarkan menjadi tiga bagian yaitu: perhatian terhadap bahan pelajaran, memahami materi pelajaran dan menyelesaikan soal-soal pelajaran. Ketertarikan dibedakan menjadi ketertarikan terhadap bahan pelajaran dan untuk menyelesaikan soal-soal pelajaran. Rasa senang meliputi rasa senang mengetahui bahan belajar. Memahami bahan belajar dan kemampuan menyelesaikan soal-soal.

\section{Jenis-jenis Minat Belajar}

Dalam Rahayu (2), disebutkan menurut Guilford (1956) tentang jenis-jenis minat, yaitu sebagai berikut:

- Minat vokasional, yaitu minat yang merujuk pada bidang-bidang pekerjaan

- Minat profesional: minat keilmuan, seni dan kesejahteraan sosial 
- Minat komersial: minat pada pekerjaan dunia usaha, jual beli, periklanan,akuntansi, kesekretariatan dan lain-lain

- Minat kegiatan fisik, mekanik, kegiatan luar, dan lain-lain

- Minat avokasional, yaitu minat untuk memperoleh kepuasan atau hobi Misalnya petualang, hiburan, apresiasi, ketelitian dan lain-lain

\section{Manfaat minat belajar}

Minat belajar meupakan suatu kejiwaan yang menyertai siswa di kelas dan menemani siswa dalam belajar. Minat berperan penting dalam mencapai prestasi dan juga menambahkan kegembiraan pada setiap yang ditekuni oleh seseorang, sehingga melahirkan perhatian yang spontanitas dalam terciptanya konsentrasi dalam waktu yang lama.Dengan demikian minat merupakan landasan bagi konsentrasi.Ibarat sebuah bangunan, minat merupakan dasar dan pondasi bagi bangunan konsentrasi yang diciptakan. Fondasi itu akan semakin kokoh kalau minat semakin besar dengan terus menerus dikembangkan (Liang Gie, 1995:130).

Manfaat dari minat belajar yakni :

- Dengan belajar dapat menumbuhkan kebiasaan pada diri peserta didik

- Dengan belajar dapat menumbuhkan motivasi pada diri peserta didik dan dapat menjadikan seseorang sukses

- Dengan belajar akan menambah banyak ilmu pengetahuan

- Dapat menjadi orang yang diperlukan bagi lingkungan kita

- Dapat menambah keterampilan pada diri kita

B. Model Pembelajaran Kooperatif Tipe Numbered Head Together (NHT)

1. Pengertian Model pembelajaran kooperatif tipe Numbered Head Together (NHT)

Metode pembelajaran kooperatif tipe numbered heads together dikembangkan oleh Spencer Kagan tahun 1992. Metode pembelajaran ini memberi kesempatan kepada siswa untuk saling membagikan ide dan mempertimbangkan jawaban yang tepat. Selain itu, metode ini juga mendorong siswa untuk meningkatkan semangat kerjasama mereka. Metode ini bisa digunakan dalam semua mata pelajaran dan untuk semua tingkatan usia anak didik.

Dalam metode pembelajaran kooperatif tipe ini siswa dikelompokkan menjadi beberapa kelompok. Setiap kelompok terdiri dari siswa dengan kemampuan yang bervariasi: satu kemampuan tinggi, dua kemampuan sedang dan satu kemampuan rendah. Di sini ketergantungan positif dikembangkan, yang kemampuan kurang terbantu kemampuan yang lebih. Interaksi sosial terjadi dalam kelompok ini, ada saling komunikasi, tatap muka, diskusi dan tanggung jawab.

Kata kunci: Model Pembelajaran Numbered Head Together 
Pembelajaran kooperatif tipe Numbered Head Together merupakan salah satu tipepembelajaran kooperatif yang menekankan pada struktur khusus yang dirancang untukmempengaruhi pola interaksi siswa dan memiliki tujuan untuk meningkatkan penguasaan akademik. Tipe ini dikembangkan oleh Spenser Kagen tahun 1992 dengan melibatkan para siswa

dalam menelaah bahan yang tercakup dalam suatu pelajaran dan mengecek pemahaman mereka terhadap isi pelajaran tersebut.

Permasalahan penelitian ini:

1) Apakah pelaksanaan model pembelajaran Numbered Head Together (NHT) dapat meningkatkan kualitas pembelajaran pada mata pelajaran Pendidikan Kewarganegaraan?

2) Hambatan-hambatan apa sajakah yang dihadapi dalam pelaksanaan model

pembelajaran Numbered Head Together (NHT) pada mata pelajaran pendidikankewarganegaraan.

Penelitian ini bertujuan:

1) Untuk mendeskripsikan pelaksanaan modelpembelajaran Numbered Head Together (NHT) dapat meningkatkan kualitas pembelajaran pada mata pelajaran Pendidikan Kewarganegaraan.

2)Untuk mendeskripsikan hambatan-hambatan yang dihadapi dalam pelaksanaan model pembelajaran Numbered Head Together pada mata pelajaran pendidikan kewarganegaraan.

Metode yang digunakan adalah metode kualitatif. Fokus penelitian ini adalah pelaksanaanpembelajaran dengan menggunakan model pembelajaran Numbered Head Together (NHT) dapat meningkatkan kualitas pembelajaran, dan hambatan-hambatan yang dihadapi dalam pelaksanaan model pembelajaran Numbered Head Together (NHT) pada mata pelajaran PKn. Metode pengumpulan data adalah observasi, wawancara, dan dokumentasi. Hasil penelitian menunjukkan bahwa pelaksanaan model pembelajaran Numbered Head Together (NHT) oleh guru Pendidikan Kewarganegaraan di SMP Baiturrahmah Padang dilaksanakan dalam tiga siklus. Kegiatan belajar mengajar dalam setiap siklus selalu mengalami peningkatan dari segi kualitas. Model pembelajaran ini selain dapat mempermudah pemahaman siswa mengenai materi pelajaran juga dapat meningkatkan aktivitas belajar dan hasil belajar siswa. Peningkatan aktivitas belajar siswa diamati dan dinilai oleh peneliti dan guru kolaborator dari siklus I, siklus II dansiklus III yaitu 69,07\%; 79,50\% dan $82,09 \%$.

Peningkatan aktivitas belajar siswa dapat dilihatdari keaktifan siswa selama proses pembelajaran. Siswa menunjukkan keberaniannya untuk bertanya, mengemukakan pendapat, dan memberikan 
sanggahan atau tanggapan. Meningkatnya aktivitas belajar siswa diikuti juga dengan meningkatnya hasil belajar siswa. Hal ini dapat terlihat dari peningkatan nilai rata-rata kelas selama proses pembelajaran yaitu siklus I (68,75);siklus II (75,87); dan siklus III $(76,62)$.Hambatan yang dihadapi, diantaranya: (1) siswa kurang percaya diri; (2) malu denganteman; (3) susah konsentrasi; (4) keterbatasan waktu; (5) minimnya sumber belajar.Saran-saran yang dapat disampaikan peneliti yaitu: (1) Guru PKn, khususnya di lingkungan SMP Baiturrahmah Padang dapat menggunakan model pembelajaran Numbered Head Together (NHT) untuk meningkatkan aktivitas belajar siswa dalam mata pelajaran PKn. Hal ini dikarenakan pembelajaran tersebut memberi peluang pada siswa untuk mengoptimalkan kemampuannya dalam menyerap informasi ilmiah yang dicari dan dapat memotivasi siswa agar berperan aktif dalam pembelajaran di kelas sehingga tujuan dalam pembelajaran dapat tercapai;

(2) Guru diharapkan dapat meningkatkan peranannya sebagai motivator dan fasilitator serta memberi kesempatan kepada siswa agar lebih aktif dalam pembelajaran; (3) Model pembelajaran Numbered Head Together (NHT) tidak hanya diterapkan pada materi Kedaulatan rakyat saja tetapi juga dapat diterapkan pada materi PKn lain yang diharapkan dapat meningkatkan aktivitas belajar siswa dan hasil belajar siswa.

\section{Unsur-unsur Model pembelajaran kooperatif tipe Numbered Head}

\section{Together (NHT)}

Menurut Ibrahim (2000:28) model pembelajaran kooperatif tipe Numbered Head Together (NHT) memiliki unsur-unsur model belajar mengajar yaitu:

a. Sitakmatik

\section{Langkah-langkah pembelajaran kooperatif NHT}

\section{Pendahuluan}

Pada pendahuluan berisi tentang persiapan antara lain:

-Guru menjelaskan tentang pembelajaran kooperatif tipe

NumberedHeads Together (NHT).

-Guru menyampaikan tujuan pembelajaran

-Guru melakukan apersepsi

-Guru memberikan motivasi pada siswa

\section{Kegiatan Inti}

Kegiatan inti adalah pelaksanaan pembelajaran kooperatif tipe Numbered Head Together (NHT).

Fase 1 : Penomoran

Penomoran

Guru membagi siswa dalam kelompok beranggotakan 4-5 orang dan kepada setiap anggota kelompok diberi nomor antara 1 sampai 5. 
Fase 2 : Mengajukan pertanyaan

Mengajukan pertanyaan : Guru mengajukan sebuah pertanyaan kepada siswa. Dalam hal ini guru memberikan pertanyan berupa lembar kerja siswa (LKS menggunakan Mcromedia Flash).

Fase 3 : Berfikir bersama

Berpikir bersama : Siswa berfikir bersama menyatukan pendapatnya terhadap jawaban pertanyaan yang berupa LKS dan meyakinkan tiap anggota dalam timnya mengetahui jawaban itu.

Fase 4 : Menjawab

Menjawab : Guru memanggil satu nomor tertentu, kemudian siswa yang nomornya sesuai mengacungkan tangannya dan mencoba menjawab pertanyaan di depan kelas.

\section{Penutup}

Penutup merupakan tahap evaluasi.

-Dengan bimbingan guru siswa membuat kesimpulan.

-Siswa diberi PR dari buku paket atau buku panduan lain.

b. Sistem Sosial

Sistem sosial yang berlaku dalam model pembelajaran

kooperatif tipe Numbered Head Togerther (NHT) adalah:

-Siswa diberi pengarahan untuk berdiskusi bersama kelompoknya.

-Siswa bebas untuk mengemukakan pendapatnya, mengajukan pertanyaan dan menjawab pertanyaan.

c. Prinsip Reaksi

Prinsip reaksi model pembelajran kooperatif tipe Numbered

Head Together (NHT) adalah:

-Guru menjelaskan tentang cara pembelajaran yang akandilaksanakan.

-Guru membagi siswa dalam bentuk kelompok. Setiap kelompok terdiri dari empat sampai lima orang siswa dan setiap kelompok mendapat nomor yang berbeda.

-Guru menyampaikan materi pembelajaran

-Guru memberikan pertanyaan yang berupa LKS.

-Guru memberikan pengarahan siswa untuk berdiskusi dalam kelompok guna menyelesaikan permasalahan.

-Guru menunjuk salah satu nomor siswa secara acak untuk menjawab pertanyaan di depan kelas.

\section{Langkah-langkah Model pembelajaran kooperatif tipe Numbered Head Together (NHT)}

Langkah-langkah tersebut kemudian dikembangkan oleh Ibrahim (2000: 29) menjadi enam langkah sebagai berikut :

\section{Langkah 1 Persiapan}


Dalam tahap ini guru mempersiapkan rancangan pelajaan dengan membuat Scenario Pembelajaran (SP), Lembar kerja siswa (LKS) yang sesuai dengan model pembelajaran Koopeatif tipe NHT.

Langkah 2 Pembentukan kelompok

Dalam pembentukan kelompok disesuaikan dengan model pembelajaran Kooperratif tipe NHT. Guru membagi para siswa menjadi beberapa kelompok yang beranggotakan 3-5 orang siswa. Guru memberi nomor kepada setiap siswa dalam kelompok dannama kelompok yang berbeda. Penomoran adalah hal yang utama di dalam NHT, dalam tahap ini guru membagi siswa menjadi beberapa kelompok atau tim yang beranggotakan tiga sampai lima orang dan memberi siswa nomor sehingga setiap siswa dalam tim mempunyai nomor berbeda-beda, sesuai dengan jumlah siswa di dalam kelompok.

Kelompok yang dibentukmerupakan percampuran yang ditinjau dari latar belakang social, ras, suku, jenis kelamin dan kemampuan belajar.Selain itu, dalam pembentukan kelompok digunakan nilai tes awal (pre-test) sebagai dasar dalam menentukan masing-masing kelompok.

\section{Langkah 3 Tiap kelompok harus memiliki buku paket atau buku} panduan

Dalam pembentukan kelompok, tiap kelompok harus memiliki buku paket atau buku panduan agar memudahkan siswa dalam menyelesaikan LKS atau masalah yang diberikan oleh guru.

\section{Langkah 4 Diskusi masalah}

Dalam kerja kelompok, guru membagikan LKS kepada setiap siswa sebagai bahan yang akan dipelajari. Dalam kerja kelompok setiap siswa berpikir bersama untuk menggambarkan dan meyakinkan bahwa tiap orang mengetahui jawaban dari pertanyaan yang telah ada dalam LKS atau pertanyaan yang telah diberikan oleh guru.Pertanyaan dapat bervariasi, dari yang bersifat spesifik sampai yang bersifat umum.

\section{Langkah 5 Memanggil nomor anggota atau pemberian jawaban}

Dalam tahap ini, guru menyebut satu nomor dan para siswa dari tiap kelompok dengan nomor yang sama mengangkat tangan dan menyiapkan jawaban kepada siswa di kelas.

\section{Langkah 6 Memberi kesimpulan}

Guru bersama siswa menyimpulkan jawaban akhir dari semua pertanyaan yang berhubungan dengan materi yang disajikan.

\section{Manfaat Model pembelajaran kooperatif tipe Numbered Head Together (NHT)}

Ada beberapa manfaat pada model pembelajaran kooperatif tipe NHT terhadap siswa yang hasil belajar rendah yang dikemukakan oleh Lundgren dalam Ibrahim (2000:18), antara lain adalah :

a). Mengembangkan rasa ingin tahu

b). Mengembangkan rasa saling memiliki dan kerja sama

c). Rasa harga diri menjadi lebih tinggi 

d). Memperbaiki kehadiran
e). Penerimaan terhadap individu menjadi lebih besar
f). Perilaku menganggu menjadi lebih kecil
g). Konflik antara pribadi berkurang
h). Pemahaman yang lebih mendalam
i). Meningkatkan kebaikan budi pekerti, kepekaan dan toleransi
j). Hasil belajar lebih tinggi
C. Pendidikan Kewarganegaraan
1. Pengertian Pendidikan Kewarganegaraan

Pengertian Pendidikan Kewarganegaraan menurut Peraturan Menteri Pendidikan Nasional Nomor 22 Tahun 2006 tentang Standar Isi untuk Satuan Pendidikan Dasar dan menengah adalah mata pelajaran yang memfokuskan pada pembentukan warga Negara yang memahami dan melaksanakan hak-hak dan kewajibannya untuk menjadi warga negara Indonesia yang cerdas, terampil dan berkarakter yang diamanatkan oleh Pancasila dan UUD1945.

Kemudian menurut Azis Wahab Cholisin, 2000.18) menyatakan bahwa PKn ialah media pengajaran yang mengindonesiakan para siswa secara sadar, cerdas dan penuh tanggung jawab. Karena itu, program PKn memuat konsep-konsep umum ketatanegaraan, politik dan hokum Negara, serta teori umum yang lain yang cocok dengan target tersebut.

Berbeda dengan pendapat diatas pendidikan kewarganegaraan diartikan sebagai penyiapan generasi muda (siswa) untuk menjadi warga Negara yang memiliki pengetahuan, kecakapan dan nilai-nilai yang diperlukan untuk berpartisipasi aktif dalam masyarakatnya (Samsuri, 2011:28).

Berdasarkan beberapa pendapat tersebut dapat dikemukakan bahwa Pendidikan Kewarganegaraan adalah suatu mata pelajaran yang merupakan satu rangkaian proses untuk mengarahkan peserta didik menjadi warga Negara yang berkarakter bangsa Indonesia, cerdas, terampil dan bertanggung jawab sehingga dapat berperan aktif dalam masyarakat sesuai dengan ketentuan Pancasila dan UUD 1945.

\section{Ruang Lingkup Pendidikan Kewarganegaraan}

Ruang Lingkup Pendidikan Kewarganegaraan diatur dalam

Permendiknas No 22 Tahun 2006 tentang Standar Isi untuk Satuan

Pendidikan Dasar dan Menengah. Ruang Lingkup mata pelajaran PKn untuk pendidikan dasar dan menengah secara umum meliputi aspekaspek sebagai berikut :

a.Persatuan dan kesatuan bangsa, meliputi hidup rukun dalam perbedaan,cinta lingkungan, kebanggaan sebagai bangsa Indonesia, sumpah pemuda, keutuhan Negara Kesatuan Republik Indonesia, partisipasi dalam pembelaan Negara, sikap positif terhadap Negara Kesatuan Republik Indonesia, keterbukaan dan jamina keadilan. 
b. Norma, Hukum dan Peraturan meliputi tertib dalam kehidupan keluarga, tata tertib sekolah, norma yang berlaku di masyarakat, peraturan-peraturan daerah, norma-norma dalam kehidupan berbangsa dan bernegara, system hukum dan peradilan nasional, hukum dan peradilan internasional.

c. Hak Asasi Manusia, meliputi hak dan kewajiban anak, hak dan kewajiban anggota masyaakat, Instrumen nasional dan internasional HAM, pemajuan penghormatan dan perlindungan HAM.

d. Kebutuhan warga Negara, meliputi hidup gotong royong, harga diri sebagai masyarakat, kebebasan berorganisasi, kemerdekaan mengeluarkan pendapat, menghargai keputusan bersama, prestasi diri, persamaan kedudukan warga Negara.

e. Konstitusi Negara, meliputi proklamasi kemerdekaan dan konstitusi yang pertama, konstitusi-konstitusi yang pernah digunakan di Indonesia, hubungan dasar Negara dengan konstitusi.

f. Kekuasaan dan politik, meliputi pemerintahan desa dan kecamatan, pemerintahan daerah dan otonomi, pemerintah pusat, demokrasi dan system politik, budaya politik, budaya demokrasi menuju masyarakat madani, system pemerintahan, pers dalam masyarakat demokrasi.

g. Pancasila meliputi kedudukan pancasila sebagai dasar Negara dan ideology Negara, proses perumusan pancasila sebagai dasar Negara, pengamalan nilai-nilai pancasila dalam kehidupan sehari-hari, pancasila sebagai ideology terbuka.

h. Globalisasi, meliputi globalisasi dilingkungannya, politik lua negeri Indonesia di era globalisasi, dampak globalisasi, hubungan internasional dan organisasi internasional dan mengevaluasi globalisasi.

Berdasarkan ruang lingkup PKn diatas, diketahui materi yang ada dalam PKn terdiri dari diantaranya tentang materi nilai-nilai, norma dan peraturan hokum yang mengatur perilaku Warga Negara sehingga diharapkan peserta didik dapat mengamalkan materi tersebut dalam kehidupan sehari-hari menjadi karakter pribadi yang melekat pada setiap individu peserta didik.

\section{Tujuan Belajar Pendidikan Kewarganegaraan}

Tujuan Belajar Pendidikan Kewarganegaraan diatur dalam Permendiknas Nomor 22 Tahun 2006 tentang Standar Isi untuk Satuan Pendidikan Dasar dan Menengah. Tujuannya adalah agar peserta didik memiliki kemampuan sebagai berikut:

a. Berpartisipasi secara aktif dan bertanggung jawab, dan bertindak secara cerdas dalam kegiatan bermasyarakat, berbangsa dan bernegara, serta anti korupsi.

b. Berpikir secara kritis, rasional dan kreatif dalam menanggapi isu kewarganegaraan 
c. Berkembang secara positif dan demokratis untuk membentuk diri berdasarkan karakter-karakter masyarakat Indonesia agar dapat hidup bersama dengan bangsa-bangsa lain.

d. Berinteraksi dengan bangsa-bangsa lain dalam percaturan dunia secara langsung atau tidak langsung dengan memanfaatkan teknologi informasi dan komunikasi.

Berdasarkan pemaparan diatas dapat dikemukakan tujuan Pendidikan Kewarganegaraan dapat diartikan sebagai mata pelajaran yang focus pada pembentukan Warga Negara yang memiliki keterampilan intelektual, keterampilan berpartisipasi dalam setiap kegiatan kewarganegaraan dan memiliki karakter kewarganegaraan yang kuat sehingga menjadikan warga Negara yang cerdas dan berkarakter.

\section{METODE PENELITIAN}

\section{A. Jenis Penelitian}

Jenis penelitian ini adalah penelitian tindakan kelas (PTK), menurut Hopkins (dalam Masnur 2012: 8) menyatakan PTK adalah suatu bentuk kajian yang bersifat reflektif yang dilakukan oleh pelaku tindakan untuk meningkatkan kemantapan rasional dari tindakan-tindakannya dalam melaksanakan tugas dan memperdalam pemahaman terhadap kondisi dalam praktik pembelajaran. Penelitian tindakan adalah kajian tentang situasi sosial dengan maksud untuk meningkatkan kualitas tindakan di dalamnya. Seluruh proses, telaah, diagnosis, perencanaan, pelaksanaan, pemantauan dan pengaruh menciptakan hubungan yang diperlukan antara evaluasi diri dan perkembangan profesional. Lebih lanjut penelitian tindakan kelas adalah penelitian tindakan yang dilakukan dikelas dengan tujuan memperbaiki mutu praktik pembelajaran dikelasnya. Kelas merupakan sekelompok siswa menerima pelajaran yang sama dari guru yang sama. Pelaksanaan penelitian tindakan kelas menggabungkan tindakan bermakna dengan prosedur penelitian yang merupakan suatu upaya memecahkan masalah sekaligus mencari dukungan ilmiah.

Tujuan penelitian tindakan kelas adalah untuk meperbaiki berbagai persoalan nyata dan praktis dalam peningkatan mutu pembelajaran di kelas yang dialami langsung dalam interaksi antara guru dengan siswa yang sedang belajar.

Pada tahap ini peneliti menggunakan model pembelajaran kooperatif tipe Numbered Head Together (NHT) untuk meningkatkan minat belajar siswa pada mata pelajaran PKn kelas VIII SMP Baiturrahmah Padang.

1. Sabjek Penelitian 
Subjek penelitian ini adalah kelas VIII berjumlah17 orang, yang terdiri dari 13 orang siswa laki-laki dan 4 orang siswa perempuan.

2. Tempat dan waktu pelaksanaan

Penelitin ini dilaksanakan di SMP Baiturrahmah Padang, J1 Damar 1 No. 8, Kecamatan Padang Selatan. Waktu pelaksanaan penelitian ini periode Januari-Juni semester 2 (Genap).

3. Alat Pengumpulan Data

Alat yang dipakai untuk mengumpulkan data ini diantaranya dokumen, isian angket, instrumen/ soal dan wawancara.

4. Alat Pengelohan Data

alat pengolahan data yang digunakan dalam penelitian ini adalah tehnik kualitatif dan persentase sederhana.

\section{B. Prosedur Penelitian}

1. Perencanaan (Planning)

Kegiatan yang dilakukan pada perencanaan adalah :

a. Menentukan jadwal penelitian

b. Menentukan materi yang akan diajarkan

c. Menyiapkan rencana pelaksanaan pembelajaran (RPP)

d. Menyiapkan lembar instrument penelitian

e. Membuat lembar observasi

2. Pelaksanaan (Action)

Kegiatan yang dilaksanakan pada tahap ini adalah pelaksanaan scenario pembelajaran yang telah dipersiapkan sebelumnya. Pada saat masuk kelas guru memberi salam dan mengabsensi siswa serta melakukan apersepsi, kemudian guru menyampaikan kompetensi yang hendak dicapai dan batasan materi yang akan dipelajari. Pada tahap ini guru bersama dengan peneliti melaksanakan proses belaja mengajar sesuai dengan scenario pembelajaran yang telah disepakati.

3. Pengamatan (Observation)

Pengamatan yang dilakukan selama proses belajar mengajar berlangsung yang berpedoman pada instrument penelitian untuk melihat minat belajar siswa pada mata pelajaran Pendidikan Kewarganegaraan kelas VIII SMP Baiturrahmah Padang. Pengamatan ini dilakukan selama peneliti berada dalam kelas untuk melihat minat belajar sejarah siswa, adapun indicator minat yang diamati yaitu rasa senang, rasa ingin tahu dan keaktifan siswa. Selanjutnya peneliti mengolah data yang telah I dapat melalui lembar observasi dalam bentuk tally menjadi data persentase dan peneliti menganalisis indikator yang telah dilaksanakan.

4. Refleksi (Reflection)

Setelah kegiatan selesai dilakukan refleksi dengan tujuan mengkaji secara menyeluruh yang telah dilakukan pada siklus 1, sehingga ditemukan kelebihan dan kekurangan dari tindakan tersebut. Berdasakan semua data yang telah diperoleh pada pelaksanaan siklus 1, maka hasil analisis tersebut digunakan untuk perbaikan pelaksanaan proses pembelajaran pada siklus berikutnya. Peneliti bersama observer 
mendiskusikan tindakan yang telah dilaksanakan dengan dilaksanakan dengan melihat butir-butir indicator yang dianggap bermasalah.

\section{HASIL DAN PEMBAHASAN}

\section{A. Studi Pendahuluan/Diskripsi Awal/ Pra Siklus}

Dari data yang dikumpulkan melalui dokumen dan data emperis (pengalaman) tentang minat belajar siswa rendah, untuk lebih jelasnya dapat dibaca pada tabel di bawah ini:

Tabel 1. Data Studi Awal

\begin{tabular}{|c|c|c|c|c|c|c|c|c|c|}
\hline \multirow[t]{3}{*}{ No } & \multirow[t]{3}{*}{ Nama Siswa } & \multicolumn{2}{|c|}{ Jenis Kelamin } & \multicolumn{6}{|c|}{ Minat Belajar } \\
\hline & & \multirow[t]{2}{*}{ LK } & \multirow[t]{2}{*}{ PR } & \multicolumn{2}{|c|}{ Rendah } & \multicolumn{2}{|c|}{ Sedang } & \multicolumn{2}{|c|}{$\begin{array}{c}\text { Tingg } \\
\mathbf{i}\end{array}$} \\
\hline & & & & Jml & $\%$ & Jml & $\%$ & $\begin{array}{c}\mathrm{J} \\
\mathbf{m} \\
\mathbf{1}\end{array}$ & $\%$ \\
\hline 1 & ALDO FEBRIAN & $\checkmark$ & & $\checkmark$ & & & & & \\
\hline 2 & ANISYA RAHMAN & & $\checkmark$ & $\checkmark$ & & & & & \\
\hline 3 & ANDRIANSYAH & $\checkmark$ & & $\checkmark$ & & & & & \\
\hline 4 & FILO STEPHAN & $\checkmark$ & & & & $\checkmark$ & & & \\
\hline 5 & GALANG HIDAYATULLAH & $\checkmark$ & & $\checkmark$ & & & & & \\
\hline 6 & NABILA ARIFIN & & $\checkmark$ & & & $\checkmark$ & & & \\
\hline 7 & HASBIL & $\checkmark$ & & $\checkmark$ & & & & & \\
\hline 8 & $\begin{array}{l}\text { HAQQUL FITTAHU } \\
\text { WAZULKARNAIN }\end{array}$ & $\checkmark$ & & $\checkmark$ & & & & & \\
\hline 9 & M. RIZKY AKBAR & $\checkmark$ & & $\checkmark$ & & & & & \\
\hline 10 & M. ZAKY ALFAJRI & $\checkmark$ & & $\checkmark$ & & $\sqrt{ }$ & & & \\
\hline 11 & ROHID CHANDRA FAISAL & $\checkmark$ & & $\checkmark$ & & & & & \\
\hline 12 & NADILA ISWANTO & & $\checkmark$ & & & & & & \\
\hline 13 & WAHYU SAPUTRA & $\checkmark$ & & & & & & & \\
\hline 14 & MUHAMMAD VAIRISKY & $\checkmark$ & & $\checkmark$ & & & & & \\
\hline 15 & DENY MUHAMMAD RIDWAN & $\checkmark$ & & $\checkmark$ & & $\checkmark$ & & & \\
\hline 16 & VERA NARYA GEE & & $\checkmark$ & $\checkmark$ & & & & & \\
\hline 17 & DEVYN FAID MAULANA & $\checkmark$ & & $\checkmark$ & & & & & \\
\hline & JUMLAH & $\begin{array}{l}\mathrm{LK}=13 \\
\mathrm{PR}=4\end{array}$ & & $\begin{array}{c}10 \\
3\end{array}$ & $\begin{array}{l}76 \\
18\end{array}$ & $\begin{array}{l}3 \\
1\end{array}$ & $\begin{array}{c}18 \\
6\end{array}$ & 0 & 0 \\
\hline & & & & 13 & 94 & 4 & 24 & 0 & 0 \\
\hline
\end{tabular}


1. Kategori Minat Belajar Rendah

Dari tabel diatas terlihat jumlah siswa laki-laki 13 orang ternyata 10 orang minat belajarnya berada pada ketegori rendah, sedangkan untuk siswa perempuan berdasarkan tabel 1 terlihat jumlah siswa perempuan 4 orang ternyata 3 orang minat belajarnya berada pada kategori rendah.

2. Kategori Minat Belajar Sedang

Dari tabel diatas terlihat jumlah siswa laki-laki 13 orang ternyata 3 orang minat belajarnya berada pada kategori sedang, sedangkan untuk siswa perempuan berdasarkan tabel 1 terlihat jumlah siswa perempuan 4 orang ternyata 1 orang minat belajarnya berada pada kategori sedang.

3. Kategori Minat Belajar Tinggi

Dari tabel di atas terlihat bahwa belum ada siswa yang memiliki minat belajar yang berada pada kategori tinggi.

\section{B. Siklus Satu}

\section{Perencanaan}

Adapun perencanaan dalam kegiatan ini:

- Mempersiapkan perencanaan

- Mempersiapkan alat peraga

- Mempersiapkan bahan ajar

- Mempersiapkan instrumen tes/ soal-soal yang diperlukan

2. Pelaksanaan

Adapun kegiatan penulis pada pelaksanaan ini sesuai dengan program yang telah disusun pada perencanaan (RPP) seperti:

a. Kegiatan Pendahuluan

- Apersepsi (Mengaitkan materi/tema/kegiatan pembelajaran yang akan dilakukan dengan pengalaman peserta didik dengan materi/tema/kegiatan pembelajaran sebelumnya (materi/tema/kegiatan) pembelajaran sebelumnya (materi kelas VII)

- Memotivasi

- Memberikan acuan setelah kegiatan pembelajaran dilaksanakan. Peserta didik diharapkan dapat:

- Makna Kedudukan, fungsi dan arti penting Pancasila sebagai Dasar negara dan pandangan hidup bangsa

- Menjelaskan Nilai-nilai Pancasila sebagai Dasar negara dan pandangan hidup bangsa

- Mengidentifikasi perilaku-perilaku yang sesuai dengan nilai-nilai Pancasila sebagai Dasar negara dan pandangan

b. Kegiatan Inti hidup bangsa

\section{Stimulan (Pemberian Rangsangan)}

Peserta didik diberi motivasi atau rangsangan untuk memusatkan perhatian dengan mengamati gambar yang berkaitan dengan (Persatuan dan kesatuan bangsa, Norma, Hukum dan Peraturan, 
Hak Asasi Manusia,Kebutuhan warga Negara, Konstitusi Negara, Kekuasaan dan politik, Pancasila \&Globalisasi).

\section{Problem Statement}

Melalui membaca dan mengamati gambar yang telah disediakan siswa dapat mengajukan / membuat pertanyaan (Untuk kondisi siswa yang aktif). Jika kondisi siswa pasif guru merangsang siswa untuk aktif mengajukan pertanyaan, misalnya :

1. Jelaskanlah makna dari Kedudukan, fungsi,dan arti penting Pancasila sebagai Dasar negara dan pandangan hidup bangsa?

2. Adakah Nilai-nilai Pancasila sebagai Dasar negara dan pandangan hidup bangsa dalam kehidupan sehari-hari?

3. Adakah membiasakan perilaku-perilaku yang sesuai dengan nilai-nilai Pancasila sebagai Dasar negara dan pandangan hidup bangsa?

\section{Data Collection}

1. Peserta didik ditugaskan untuk membuat resume tentang makna dari Kedudukan, fungsi,dan arti penting Pancasila sebagai Dasar negara dan pandangan hidup bangsa

2. Peserta didik mengumpulkan informasi yang relevan untuk menjawab pertanyaan yang telah diidentifikasi melalui bermacam-macam sumber yang terkait dengan identifikasi melalui bermacam-macam sumber yang terkait dengan identifikasi permasalahan dari materi makna dari Kedudukan, fungsi,dan arti penting Pancasila sebagai Dasar negara dan pandangan hidup bangsa

\section{Data Processing}

Peserta didik menganalisis informasi dari bacaan berbagai sumber untuk menjawab pertanyaan yang menyangkut tentang permasalahan dalam materi makna dari Kedudukan, fungsi,dan arti penting Pancasila sebagai Dasar negara dan pandangan hidup bangsa

\section{Verification}

- Siswa dan guru melakukan Tanya jawab berkaitan tentang pembelajaran yang dibahas

- Guru kemudian menanyakan apakah siswa sudah memahami topic pembelajaran yang dibahas

\section{c. Kegiatan Penutup (Apersepsi)}

\section{Penutup}

- Guru membimbing siswa untuk membuat butir-butir kesimpulan dari pembelajaran yang dibahas

- Guru mencek\& memberikan tugas berdasarkan tujuan pembelajaran yang belum tercapai 
- Sebagai refleksi guru menanyakan kepada peserta didik apa manfaat yang dapat diperoleh setelah belajar topic ini. Kemudian guru menegaskan pentingnya belajar tentang topic ini (seperti dijelaskan pada pengantar)

- Peserta didik diminta untuk mempelajari atau membaca materi untuk pertemuan selanjutnya yaitu materi mengenai Nilai-nilai Pancasila sebagai Dasar negara dan pandangan hidup bangsa dan perilaku-perilaku yang sesuai dengan nilainilai Pancasila sebagai Dasar negara dan pandangan hidup bangsa.

- Menutup pembelajaran dengan berdoa sesuai dengan agama

\section{Pengamatan} dan keyakinan masing-masing.

Pengamatan yang dilakukan dalam penelitian ini dilakukan dengan teman yang sejawat (sesama PKn) atau serumpun (seluruh serumpun PKn, Agama dan Sejarah) yang diamati adalah kegiatan guru (sesuai dengan RPP yang dilakukan guru atau tidak) dan kegiatan siswa. Dari pengamatan ini ditemukan peningkatan minat belajar siswa di kelas VIII pada mata pelajaran PKn, temuan ini merupakan hasil dari pelaksanaan siklus satu.

Hasil penelitian tindakan pada siklus dua dikumpulkan melalui angket, pengamatan dan analisis hasil pelaksanaan siklus dua, untuk lebih jelasnya dapat dibaca pada tabel dua.

\section{Tabel 2. Hasil Siklus I}

\begin{tabular}{|c|c|c|c|c|c|c|c|c|c|}
\hline \multirow[t]{3}{*}{$\begin{array}{c}\mathrm{N} \\
\mathrm{O}\end{array}$} & \multirow[t]{3}{*}{ Nama Siswa } & \multicolumn{2}{|c|}{$\begin{array}{c}\text { Jenis } \\
\text { Kelamin }\end{array}$} & \multicolumn{6}{|c|}{ Minat Belajar } \\
\hline & & \multirow[t]{2}{*}{ LK } & \multirow[t]{2}{*}{ PR } & \multicolumn{2}{|c|}{ Rendah } & \multicolumn{2}{|c|}{ Sedang } & \multicolumn{2}{|c|}{ Tinggi } \\
\hline & & & & Jml & $\%$ & $\mathrm{Jml}$ & $\%$ & $\mathrm{Jml}$ & $\%$ \\
\hline 1 & ALDO FEBRIAN & $\checkmark$ & & & & $\sqrt{ }$ & & & \\
\hline 2 & ANISYA RAHMAN & & $\sqrt{ }$ & & & $\sqrt{ }$ & & & \\
\hline 3 & ANDRIANSYAH & $\sqrt{ }$ & & $\sqrt{ }$ & & & & $\checkmark$ & \\
\hline 4 & FILO STEPHAN & $\checkmark$ & & & & & & $\checkmark$ & \\
\hline 5 & $\begin{array}{l}\text { GALANG } \\
\text { HIDAYATULLAH }\end{array}$ & $\checkmark$ & & & & & & $\checkmark$ & \\
\hline 6 & NABILA ARIFIN & $\sqrt{ }$ & & & & & & & \\
\hline 7 & HASBIL & $\checkmark$ & & & & & & $\checkmark$ & \\
\hline 8 & $\begin{array}{l}\text { HAQQUL FITTAHU } \\
\text { WAZULKARNAIN }\end{array}$ & $\sqrt{ }$ & & & & & & $\checkmark$ & \\
\hline 9 & M. RIZKY AKBAR & $\sqrt{ }$ & & & & & & $\checkmark$ & \\
\hline 10 & M. ZAKY ALFAJRI & $\checkmark$ & & & & & & $\checkmark$ & \\
\hline 11 & $\begin{array}{l}\text { ROHID CHANDRA } \\
\text { FAISAL }\end{array}$ & $\sqrt{ }$ & & & & $\checkmark$ & & & \\
\hline 12 & NADILA ISWANTO & & $\sqrt{ }$ & & & & & $\checkmark$ & \\
\hline
\end{tabular}




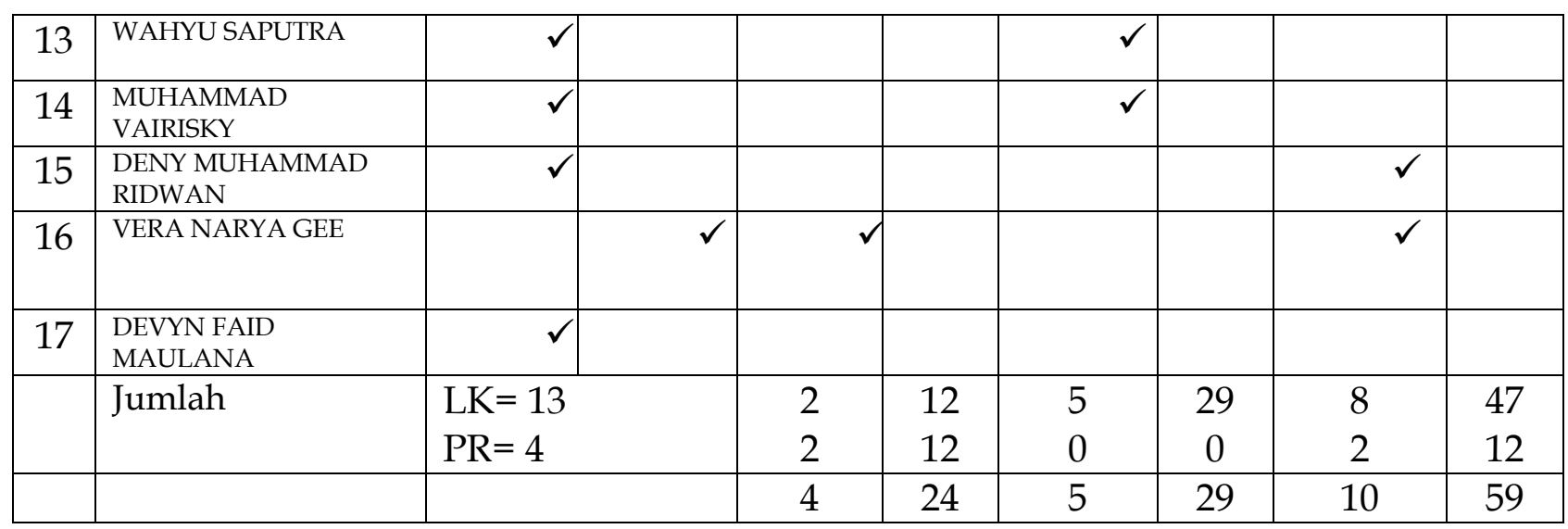

4. Refleksi

Refleksi dilaksanakan untuk melakukan analisis pelaksanaan siklus satu untuk me;lihat kelebihan dan kekurangan pada siklus satu yaitu siswa kurang kompak dalam memecahkan masalah Kelebihan yaitu siswa aktif dalam pembelajaran oleh karena itu kelebihan pada siklus satu dilanjutkan untuk siklus dua. Refleksi dilakukan untuk menyusun perencanaan pada siklus Dua.

C. Siklus Dua

\section{PERENCANAAN}

Adapun perencanaan dalam kegiatan ini

a.Merevisi dan melengkapi perencanaan pembelajaran RPP

b.Merevisi dan melengkapi alat peraga

c.Merevisi dan melengkapi bahan ajar

d.Merevisi dan melengkapi instrumen tes/ soal-soal yang diperlukan

2. Pelaksanaan

Adapun kegiatan penulis pada pelaksanaan ini sesuai dengan program yang telah disusun pada perencanaan (RPP) seperti:

a. Kegiatan pendahuluan

- Apersepsi (Mengaitkan materi / tema/kegiatan pembelajaran yang akan dilakukan dengan pengalaman peserta didik dengan materi/tema/ kegiatan pembelajaran sebelumnya (materi kelas VII)

- Memotivasi

- Memberikan acuan setelah kegiatan pembelajaran dilaksanakan, peserta didik diharapkan dapat :

- Menjelaskan makna dari Kedudukan, fungsi dan arti penting Pancasila sebagai dasar negara dan pandangan hidup bangsa?

- Menjelaskan Nilai-nilai Pancasila sebagai dasar negara dan pandangan hidup bangsa dalam kehidupan seharihari? 
- Membiasakan perilaku-perilaku yang sesuai dengan nilai-nilai Pancasila sebagai dasar negara dan pandangan hidup bangsa dalam kehidupan sehari-hari?

b. Kegiatan inti

\section{STIMULAN (Pemberian Ransangan)}

- Peserta didik diberi motivasi atau rangsangan untuk memusatkan perhatian dengan mengamati gambar yang berkaitan dengan perilaku-perilaku yang sesuai dengan nilai-nilai Pancasila sebagai Dasar negara dan pandangan hidup bangsa dalam kehidupan sehari-hari

\section{PROBLEM STATEMENT}

Melalui membaca dan mengamati gambar yang telah disediakan siswa dapat mengajukan /membuat pertanyaan (Untuk kondisi siswa yang aktif). Jika kondisi siswa pasif guru merangsang siswa untuk aktif mengajukan pertanyaan, misalnya :

1. Contoh-contoh perilaku pelajar yang sesuai dengan nilai-nilai Pancasila?

2. Adakah membiasakan/mempraktekkan perilaku-perilaku yang sesuai dengan nilai-nilai pancasila di sekolah?

3. Apakah anda tahu bahwa sikap jujur, tidak suka mencontek, hormat pada guru, selalu melaksanakan piket, rajin mengerjakan latihan, rajin melaksanakan ibadah/ sholat Dhuha, zuhur dan Ashar di sekolah dengan tertib, tidak suka meribut dikelas merupakan perilaku-perilaku yang sesuai dengan nilainilai pancasila yang harus dibiasakan oleh pelajar disekolah?

\section{DATA COLLECTION}

1. Peserta didik ditugaskan untuk membuat resume tentang makna dari Kedudukan, fungsi dan arti penting Pancasila sebagai Dasar negara dan pandangan hidup bangsa

2. Peserta didik mengumpulkan informasi yang relevan untuk menjawab pertanyaan yang telah diidentifikasi melalui bermacam-macam sumber yang terkait dengan identifikasi melalui bermacam-macam sumber yang terkait dengan identifikasi permasalahan dari materi makna dari Kedudukan, fungsi dan arti penting Pancasila sebagai Dasar negara dan pandangan hidup bangsa

\section{DATA PROCESING}

Peserta didik menganalisis informasi dari bacaan berbagai sumber untuk menjawab pertanyaan yang menyangkut tentang permasalahan dalam materi makna dari Kedudukan, fungsi dan arti penting Pancasila sebagai Dasar negara dan pandangan hidup bangsa.

\section{VERIFICATION}

1. Siswa dan guru melakukan Tanya jawab berkaitan tentang pembelajaran yang dibahas 
2. Guru kemudian menanyakan apakah siswa sudah memahami topic pembelajaran yang dibahas.

c. Kegiatan penutup (apersepsi)

1. Guru membimbing siswa untuk membuat buti-butir kesimpulan dari pembelajaran yang dibahas

2. Guru mencek dan memberikan tugas berdasarkan tujuan pembelajaran yang belum tercapai

3. Sebagai refleksi guru menanyakan kepada peserta didik apa manfaat yang di dapat dan diperoleh setelah belajar topic ini. Kemudian guru menugaskan pentingnya belajar tentang topic ini (Seperti dijelaskan pada pengantar).

4. Peseta didik diminta untuk mempelajari atau membaca materi untuk pertemuan selanjutnya yaitu materi mengenai Nilai-nilai Pancasila sebagai Dasar negara

5. Menutup pembelajaran dengan berdo'a sesuai dengan agama dan keyakinan masing-masing.

\section{Pengamatan}

Pengamatan yang dilakukan dalam penelitian ini dilakukan dengan teman yang sejawat (sesama PKn) atau serumpun (seluruh serumpun PKn, EKO, GEO) yang diamati adalah kegiatan guru (sesuai dengan RPP yang dilakukan guru atau tidak) dan kegiatan siswa. Dari pengamatan ini ditemukan peningkatan minat belajar siswa di kelas VIII pada mata pelajaran PKn, temuan ini merupakan hasil dari pelaksanaan siklus dua.

Hasil penelitian tindakan pada siklus dua dikumpulkan melalui angket, pengamatan dan analisis hasil pelaksanaan siklus dua, untuk lebih jelasnya dapat dibaca pada tabel 3.1

Tabel 3. Hasil Siklus II

\begin{tabular}{|c|c|c|c|c|c|c|c|c|c|}
\hline \multirow{3}{*}{$\begin{array}{l}\mathrm{N} \\
\mathrm{O}\end{array}$} & \multirow{3}{*}{ NAMA SISWA } & \multicolumn{2}{|c|}{$\begin{array}{l}\text { JENIS } \\
\text { KELAMIN }\end{array}$} & \multicolumn{6}{|c|}{ MINAT BELAJAR } \\
\hline & & \multirow[t]{2}{*}{ LK } & \multirow[t]{2}{*}{ PR } & \multicolumn{2}{|c|}{ RENDAH } & \multicolumn{2}{|c|}{ SEDANG } & \multicolumn{2}{|c|}{ TINGGI } \\
\hline & & & & Jml & $\%$ & Jml & $\%$ & Jml & $\%$ \\
\hline 1 & ALDO FEBRIAN & $\sqrt{ }$ & & & & & & $\checkmark$ & \\
\hline 2 & ANISYA RAHMAN & & $\checkmark$ & & & & & $\checkmark$ & \\
\hline 3 & ANDRIANSYAH & $\sqrt{ }$ & & & & $\sqrt{ }$ & & & \\
\hline 4 & FILO STEPHAN & $\sqrt{ }$ & & & & & & $\checkmark$ & \\
\hline 5 & $\begin{array}{l}\text { GALANG } \\
\text { HIDAYATULLAH }\end{array}$ & $\checkmark$ & & & & & & $\checkmark$ & \\
\hline 6 & NABILA ARIFIN & & $\checkmark$ & & & $\sqrt{ }$ & & & \\
\hline 7 & HASBIL & $\checkmark$ & & & & & & & \\
\hline
\end{tabular}


78 | Upaya peningkatan minat...

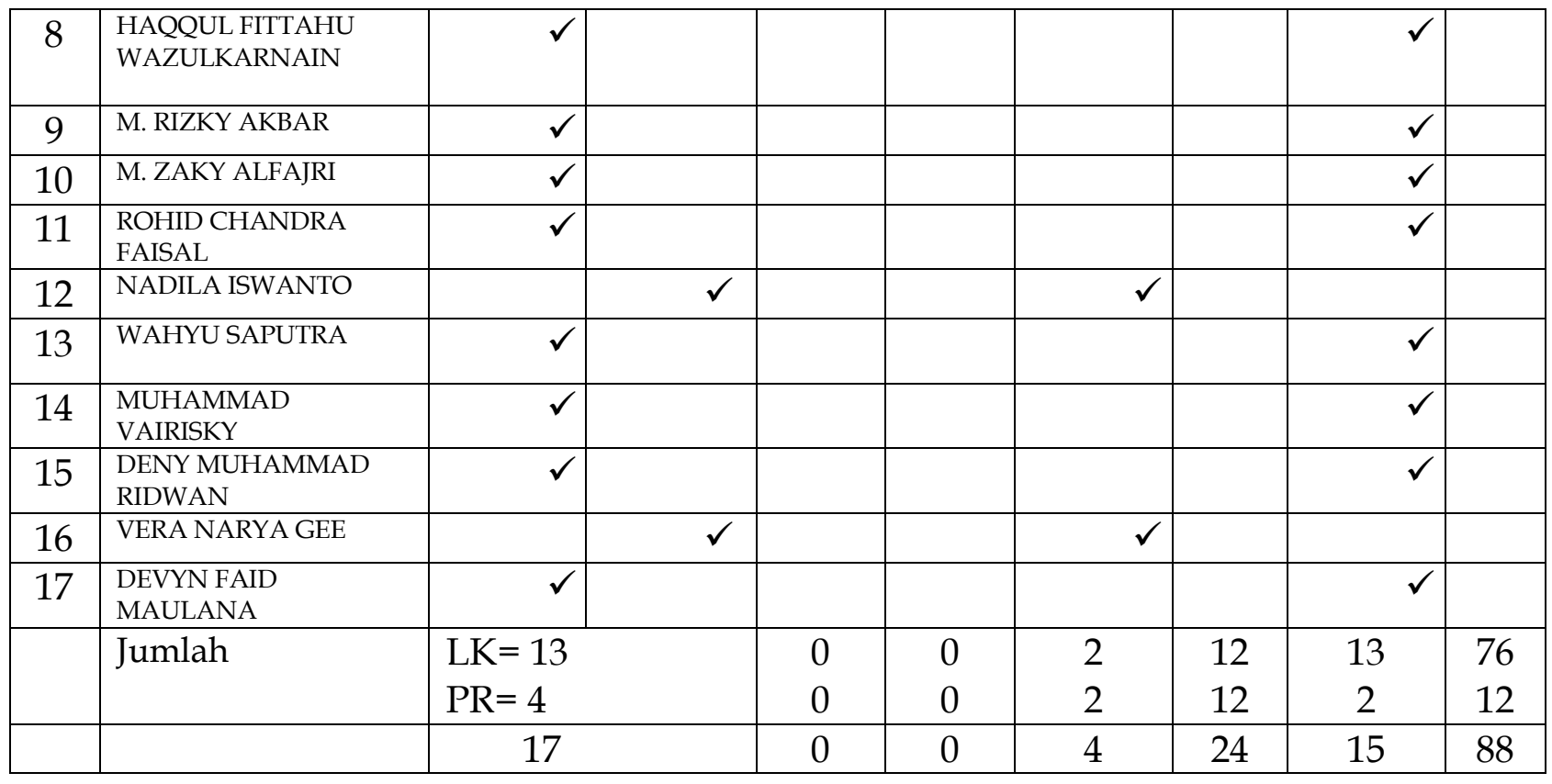

4. Refleksi

Refleksi ini dilaksanakan untuk melakukan analisis pelaksanaan siklus dua untuk melihat kelebihan dari siklus kedua yang dilaksanakan pada pembelajaran PKn.

D. Pembahasan Siklus

Pada bahagian ini peneliti akan membahas peningkatan minat belajar siswa melalui model pembelajaran kooperatif tipe Numbered Head Together (NHT) mulai dari studi awal sampai dengan pelaksanaan siklus terakhir. Untuk lebih jelas dapat dibaca pada grafik di bawah ini.

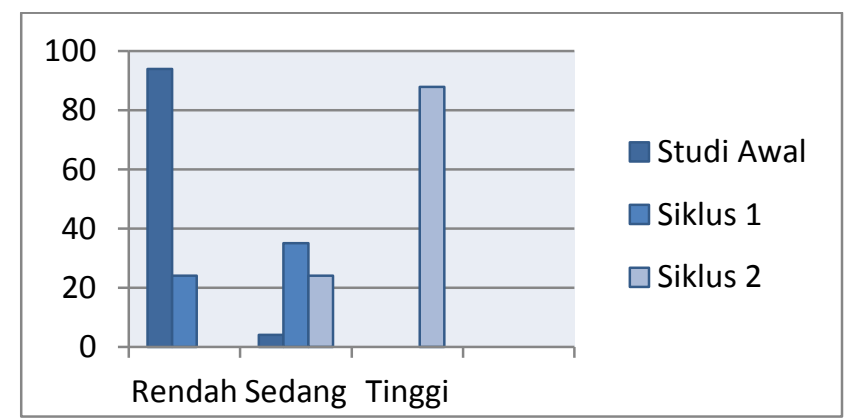

Dari grafik di atas tergambar peningkatan hasil belajar siswa mulai dari studi awal sampai berakhir pelaksanaan siklus, untuk ini dapat dibaca pada uraian berikut ini:

1. Kategori Rendah

Dari 94\% studi awal mengalami peningkatan minat belajar siswa pada siklus satu siswa yang kategori rendah sebanyak $24 \%$ dengan menggunakan model pembelajaran NHT.

2. Kategori sedang 
Dari $4 \%$ studi awal mengalami peningkatan minat belajar siswa pada siklus satu siswa yang kategori sedang sebanyak $35 \%$ dengan menggunakanmodel pembelajaran NHT.

3. Kategori Tinggi

Dari $0 \%$ studi awal mengalami peningkatan minat belajar siswa pada siklus dua siswa yang kategori tinggi sebanyak $88 \%$ dengan menggunakanmodel pembelajarran NHT.

\section{PENUTUP}

a. Kesimpulan

Berdasarkan analisis data yang diperoleh selama penelitian dapat disimpulkan bahwa penggunaan model pembelajaran kooperatif tipe Numbered Head Together meningkatkan minat belajar siswa pada mata pelajaran PKN di kelas VIII SMP Baiturrahmah Padang. Hal ini dapat dilihat dari indicator minat belajar siswa yang diamati dalam setiap pertemuan mengalami peningkatan pada setiap siklus.

Meningkatnya minat belajar siswa, karena proses pembelajaran tidak hanya terpusat pada guru. Model pembelajaran kooperatif tipe Numbered Head Together memberikan kesempatan kepada siswa untuk berinteaksi dengan teman dalam membahas permasalahan yang dipelajai di dalam kelas.

Dengan siswa mengamati, lalu bisa menanya, menjawab dan mengkomunikasikan sehingga hal ini membuat siswa terbiasa mengaktifkan pengetahuan dan keterampilan yang sudah ada, untuk memperoleh pengetahuan baru melalui penemuan dengan cara mengamati, lalu siswa bisa menanya, menjawab dan mengkomunikasikan sehingga hal ini membuat siswa terbiasa mengaktifkan pengetahuan dan keterampilan yang sudah ada, untuk memperoleh pengetahuan baru melalui penemuan dengan cara mengamati.

Siswa dibagi dalam kelompok kecil yang masing-masing siswa memiliki nomor yang nantinya akan menarik perhatian siswa, sehingga masingmasing siswa bersiap-siap dengan ide-ide masing-masing dalam pemecahan masalah. Selain itu model pembelajaran kooperatif tipe Numbered Head Together dapat membantu guru untuk membantu guru untuk membuat siswa lebih aktif, lebih memahami dan lebih mampu berkomunikasi dilengkapi dengan model pembelajaran yang sesuai dengan penggunaan media ini.

b. Saran

1. Penelitian ini telah berhasil dilaksanakan dengan subjek siswa kelas VIII SMP Baiturrahmah Padang dalam mata pelajaran PKN, tetapi untuk pengembangan lebih jauh disarankan untuk melakukan penelitian lanjutan pada kelas dan mata pelajaran lainnya.

2. Disarankan dalam pembelajaan yang menggunakan model pembelajaran kooperatif tipe Numbered Head Together (NHT) tiddak hanya bertumpu 
80 | Upaya peningkatan minat...

pada siswa kategori baik saja namun untuk semua siswa. Serta sediakan soal sesuai dengan tema agar memudahkan siswa dalam berdiskusi.

\section{DAFTAR PUSTAKA}

Kementerian Pendidikan dan Kebudayaan. 2013. Pendidikan Pancasila dan Kewarganegaraan, kelas VIII Jakarta: Kementerian Pendidikan dan Kebudayaan. Halaman: 1 